\title{
Water Deficit Stress Tolerance in Some of Barley Genotypes and Landraces under Field Conditions
}

\author{
Alireza POUR ABOUGHADAREH ${ }^{\circ *}$, Mohammad Reza NAGHAVI ${ }^{2}$, Marouf KHALILI $^{3}$ \\ ${ }^{1}$ Payame Noor University of Ilam Center, Department of Agronomy, Ilam, Iran; a.poraboghadareh@yahoo.com (*corresponding author) \\ ${ }^{2}$ Payame Noor University of Ghare Aghaj Center, Department of Agronomy, East Azerbaijan, Iran \\ ${ }^{3}$ Payame Noor University of Mahabad Center, Department of Agronomy, West Azerbaijan, Iran
}

\begin{abstract}
In order to investigate the effects of water deficit stress on some agro-morphological and physiological traits of seven genotypes and five landraces of barley, a split plot experiment was conducted a completely randomized block design with four replications in 2011-2012 cropping season at experimental field of College of Agriculture, Payame Noor University of Center, West Azerbaijan, Iran. Analysis of variance revealed significant differences among genotypes and landraces for all of the studied traits, and showed highly significant effects of water deficit stress on all the studied traits. Based on correlation analysis, all the characters included in the study except leaf temperature and number of grain per spike showed significant positive correlation with grain yield under both conditions. In terms of physiological characters high significant correlation coefficient was found between relative water content and grain yield under stress condition; however, high significant correlation coefficient observed between fluorescence chlorophyll and grain yield under non-stress condition. 1000-grain weight had negative correlation with all characters except leaf temperature under non-stress condition. However, this character had significant and positive correlation with fluorescence chlorophyll, relative water content, SPAD value, spike length, number of spike per plant under stress condition. Considering the grain yield potential 'Naghadeh', 'Piranshahr' and 'Mahabad' landraces together with 'CW3117-77' genotype were ranked as the superior group of drought tolerant barley. On the other hand, 'Naghadeh' landrace was identified as a barley landrace that could be grown under both normal and water deficit stress conditions with high grain yield.
\end{abstract}

Keywords: agro-morphological traits, barley, correlation, drought tolerance, physiological characteristics

\section{Introduction}

Barley (Hordeum vulgar L.) is a major crop ranked fourth in the world-wide production of cereals. It is considered a primary staple food or feed crop in the semi-arid tropics of Asia, Africa, and South America. The grain is normally used as food and animal fodder, but recently it has been used as raw material for the production of beer. Barley is typically cultivated in the arid and semi-arid regions of Iran generally in areas with low precipitation that are not suitable for wheat (Baik and Ullrich, 2008). Drought is a significant limiting factor for agricultural productivity and generally inhibits plant growth through reduced water absorption and nutrient uptake. For improving the drought tolerance of crop varieties by plant breeding, it is necessary to identify genotypes with tolerance to drought stress during all growth stages. Landraces are still cultivated in traditional crop-growing areas. There is renewed interest in landraces and primitive cultivars as important sources of genetic variation (Brush, 1995) mainly because of the trend toward greater uniformity that has narrowed the genetic base of modern cultivars, thus increasing their vulnerability to biotic and abiotic stress (Moghaddam et al., 1997).
Decreased water availability generally results in reduced growth and final yield in crop plants. Plant drought tolerance is a highly complex trait that involves multiple genetic, physiological and biochemical mechanisms (Baik and Ullrich, 2008; Erdei et al., 2002). Drought affects morphological, physiological, biochemical and molecular processes in plants resulting in growth inhibition. The extent of these changes is dependent on the time, stage and severity of environmental stress (Cao et al., 2011). Measurements of different physiological processes of plants responses to drought are important information on the various strategies of the plant intended to remove or to reduce the harmful effects of water deficit in soil or plant tissues. Water deficit conditions cause water losses within the plant and result in relative water content (RWC) reduction. Therefore, RWC is widely used as one of the most reliable indicators for defining both the sensitivity and the tolerance of plants to water deficit (Rampino et al., 2006; Sanchez-Rodriguez et al., 2010). Rong-Hua et al. (2006) concluded that chlorophyll content could be considered as a reliable indicator in screening barley genotypes for drought tolerance. Experiments with a host of plants and different photosynthetic metabolism processes, which can be induced by varieties of plants and many biotic and abi- 
250

otic factors, can directly or indirectly produce modification to fluorescence induction kinetics (Crudace, 2000; Percival and Baker, 1991). In addition, Slapakauskas and Ruzgas (2005) reported that measuring of chlorophyll provides information on quantitative and quantitative changes in photosynthesis.

The search for traits related to drought tolerance is an important step in cereals breeding and production. Field experiments investigating the yields of different cultivars under water deficit conditions are the most reliable way to assess their drought tolerance. Dencic et al. (2000) reported that many morphological and physiological characteristics were affected by drought stress. Also, they reported agronomic traits such as grain yield and its components are the major selection criteria for evaluating drought tolerance under field condition. Gupta et al. (2001) studied physiological and yield attributes of two wheat genotypes with stress at boot and anthesis. They indicated that number of grains, grain yield, biological yield, and harvest index decreased to a greater extent when water stress was imposed at anthesis stage. Therefore, physiological, agromorphological and biochemical approaches have a great importance in order to understand the complex responses of plants to water deficiency and develop rapidly new varieties. A physiological approach would be the most attractive way to develop new varieties (Araus et al., 2008) but breeding for specific, sub-optimal environments involves a deeper understanding of yield-determining process.

Generally, different strategies have been proposed for the selection of relative drought tolerance and resistance, so, some researchers have proposed selection under nonstress conditions (Betran et al., 2003; Rajaram and Van Ginkle, 2001; Richards, 1996), others have suggested selection in the target stress conditions (Ceccarelli and Grando, 1991; Rathjen, 1994) while, several of them have chosen the midway and believe in selection under both non-stress and stress conditions (Byrne et al., 1995; Clarke et al., 1992; Fernandez, 1992; Fischer and Maurer, 1978). In addition to, indices such as SSI (Fischer and Maurer, 1978), TOL (Rosielle and Hamblin, 1981), STI and GMP (Fernandez, 1992), DRI (Bidinger et al., 1978), MSTI (Farshadfar and Sutka, 2002) have been reported for selection of drought tolerance genotypes.

In the present study, five landraces together seven genotypes of barley were used to assess drought tolerance. The drought tolerance has been evaluated by physiological indices, i.e. leaf RWC, RCC, chlorophyll fluorescence and agro-morphological characteristics related to grain yield, under water deficit stress conditions.

\section{Materials and methods}

\section{Plant material and growth conditions}

To investigate the effects of water deficit stress, a research was carried out at experimental field of College of Agriculture, Payame Noor University of Mahabad Center, West Azerbaijan, Iran (latitude $36.46^{\circ} \mathrm{N}$, longitude $45.43^{\circ} \mathrm{E}$, Altitude $1385 \mathrm{~m}$ above sea level) during growing season of 2011-2012. The climate is characterized by mean annual precipitation of $330 \mathrm{~mm}$, mean annual temperature of $12^{\circ} \mathrm{C}$. Plant materials consisted of twelve genotypes and landraces of barley provided from Agricultural and Natural Resources Research Center of West Azerbaijan, Iran. The names of used in this investigation are shown in Tab. 1.

Experiment was conducted in split plot within a randomized complete block design with four replications. The experimental treatments consisted of irrigation levels as the main plot at second levels: irrigation after $70 \mathrm{~mm}$ evaporation from class A pan (without stress), irrigation after $150 \mathrm{~mm}$ evaporation from class A pan (water deficit stress) and twelve genotypes and landraces of barley as the sub plot were considered. Each plot contained 4 rows with $25 \mathrm{~cm}$ apart and $1 \mathrm{~m}$ in length. All plots were irrigated after sowing and subsequent irrigations in beginning in tillering. Weeds were controlled by hand during crop growth and development.

\section{Crop sampling and calculation}

Agronomic characteristics and physiological criteria including: spike length $(\mathrm{cm})$, number of spike per plant, number of grain per spike, 1000-grains weight (gr), grain yield (gr per plant), leaf temperature, fluorescence chlorophyll, relative chlorophyll content (SPAD value) and relative water content (RWC) were measured after of physiology maturity by selected 10 plants of each experimental plot randomly. For measuring physiological criteria was used the flag leaf. The chlorophyll content in the flag leaf was determined using a chlorophyll meter (SPAD-502, Japan). Five flag leaves of each cultivar grown in stress and non-stress conditions were measured after tillering stage. Three measurements in the middle of the flag leaf were

Tab. 1. Names of barley genotypes/landraces studied in this experiment

\begin{tabular}{cccc}
\hline Code & Name & Code & Name \\
\hline 1 & 'Badia Kavirr' (genotype) & 7 & 'CB' (genotype) \\
2 & '168.4 Lign131/Abrabi Abiad' (genotype) & 8 & 'Sahand' (landrace) \\
3 & 'Mahabad' (landrace) & 9 & 'Makoobi' (landrace) \\
4 & 'Rihaner' (genotype) & 10 & 'Piranshahr' (landrace) \\
5 & 'Naghadeh' (landrace) & 11 & 'CW3117-77-5-9-5' (genotype) \\
6 & 'Atlas46/Kavir' (genotype) & 12 & 'Rihane-05' (genotype) \\
\hline
\end{tabular}


made randomly for each plant, and the average sample was used for analysis. Relative water content was determined according to Turner (1986), where fresh leaves were taken from each cultivar and each replication after tillering stage and weighed immediately to record fresh weight (FW). Then they were placed in distilled water for $4 \mathrm{~h}$ and weighed again to record turgid weight (TW). After that subjected to oven drying at $70^{\circ} \mathrm{C}$ for $24 \mathrm{~h}$ to record dry weight (DW). The RWC was calculated using the following equation:

\section{$\mathrm{RWC}=((\mathrm{FW}-\mathrm{DW}) /(\mathrm{TW}-\mathrm{DW})) \times 100$}

The chlorophyll fluorescence was measured by a chlorophyll fluorometer (Opti Science, OS-30MSA). Also, leaf temperature measurement were made using the infrared thermometer.

\section{Statistical analysis}

Simple analysis variance was performed for data using SPSS software. Mean comparisons were conducted using Duncan's multiple rang test. Percentage of reduction in characteristics due to drought stress was calculated as following:

$$
C=\frac{\bar{X} n s-\bar{X} d s}{\bar{X} n s} \times 100
$$

Where $\bar{X} n s$ the mean of characteristic in given genotype/landrace under non-stress condition and $\bar{X} d s$ is the mean of characteristic in given genotype/landrace under water deficit stress condition. Analysis of correlation coefficient between grain yield and other characteristics was used to determine the principle components influencing final grain yield (Fayaz and Arzani, 2011).

Stress susceptibility index (SSI) was calculated for each cultivar following Fischer and Maurer (1978):

$S S I=(1-Y d s / Y n s) /(1-(\bar{Y} n s / \bar{Y} n s))$

Where $Y d s$ and $Y n s$ are the grain yield under stress and non-stress conditions, $\bar{Y} n s$ and $\bar{Y} n s$ are the average grain yield of all genotype/landrace under stress and non-stress conditions.

\section{Results and discussion}

Analysis of variance revealed significant $(p \leq 0.01)$ differences among genotypes and landraces for all of the studied traits except of 1000-grains weight, and showed highly significant effects of water deficit stress on all the studied traits (Tab. 2). Water deficit stress $\times$ genotypes interactions effect was also highly significant $(p \leq 0.01)$ for all traits, suggesting different response of genotypes/landraces to each conditions. The maximum and minimum value of coefficient of variation belonged to number of spike per plant and plant height, respectively.

Means of agro-morphological and physiological characteristics under stress and non-stress conditions as well as reduction percent of reduction in the concerned characteristics due to water deficit stress are shown in Tab. 3. Leaf temperature ranged from 22.70 for 'Atlas46/Kavir' genotype and 'Sahand' landrace to 25.62 for 'CB' genotype under non stress condition; however, leaf temperature were highest under stress condition and ranged from 27.50 for 'Naghadeh' to 30.50 for 'Rihane-05'. Fluorescence chlorophyll ranged from 0.74 for 'CB' genotype to 0.80 for 'Atlas46/Kavir' genotype and 'Sahand' landrace under stress conditions, however, this characteristics were lowest under stress condition and ranged from 0.69 for 'Rihane- 05 ' to 0.74 for Naghadeh landrace. Also, SPAD value ranged from 39.95 to 43.07 for as $46 /$ Kavir under non-stress condition and ranged from 33.150 for 'Rihane-05' to 40.77 for 'Naghadeh' under stress condition. The highest reduction $(21.90 \%)$ in SPAD value due to stress was observed in 'Rihane-05' genotype. Under non-stress condition RWC ranged from 73.32 for 'CB' genotype to 81.46 for 'Sahand'; however, under stress condition this characteristic ranged from 69.08 for 'Rihane-05' to 78.93 for 'Naghadeh' landrace. The decline in RWC in 'Rihane-05' and 'Atlas46/ Kavir' genotypes due to the stress was significantly less than all other genotypes and landraces. Decline of RWC reported in many researches (Farshadfar, 2012; Farshadfar et al., 2012). Ahmadi et al. (2012) showed that, RWC decline due to stress conditions. Plant height ranged from

Tab. 2. Analysis of variance for agro-morphological traits in genotypes/landraces of barley grown under water deficit stress and normal conditions

\begin{tabular}{|c|c|c|c|c|c|c|c|c|c|c|c|}
\hline \multirow{2}{*}{ Source of variation } & \multicolumn{11}{|c|}{ MS } \\
\hline & $\mathrm{df}$ & SL & NGS & NS & GW & $\mathrm{Y}$ & $\mathrm{Ph}$ & Tem & Flu & RCC & RWC \\
\hline Replication & 3 & 0.19 & 21.25 & 0.84 & 18.43 & 1.61 & 0.56 & 1.28 & $\approx 0 \dagger \dagger \dagger$ & 0.62 & 0.47 \\
\hline Stress & 1 & $76.50^{*}$ & 135.37 & $140.16^{\circ}$ & $4501.82^{*}$ & $439.59^{*}$ & $1230.51^{*}$ & $666.76^{\circ}$ & $0.09^{*}$ & $553.44^{\prime \prime}$ & $979.24^{\circ}$ \\
\hline Error 1 & 3 & 0.16 & 21.51 & 0.64 & 17.49 & 1.36 & 0.73 & 1.031 & $\approx 0 \dagger \dagger$ & 0.716 & 0.46 \\
\hline Genotype/Landrace & 11 & $1.30^{*}$ & $25.80^{*}$ & $1.61^{*}$ & 23.77 & $2.12^{\circ}$ & 271.63 & 2.176 & $0.001^{*}$ & $7.13^{\prime \prime}$ & $13.50^{*}$ \\
\hline Interaction effect & 11 & $2.89^{* *}$ & $26.78^{*}$ & $3.92^{*}$ & $25.99^{\circ}$ & $5.44^{*}$ & $27.28^{*}$ & $4.221^{*}$ & $0.001^{*}$ & $13.08^{* \prime}$ & $23.55^{*}$ \\
\hline Error 2 & 66 & 0.42 & 8.93 & 0.58 & 12.93 & 0.91 & 0.23 & 0.59 & $\approx 0 \dagger$ & 1.55 & 3.11 \\
\hline $\mathrm{CV}(\%)$ & & 7.84 & 8.49 & 21.96 & 10.45 & 21.86 & 0.88 & 2.9 & 1.72 & 3.16 & 2.31 \\
\hline
\end{tabular}

*and ${ }^{* *}$ : Significant at the 0.05 and 0.01 probability level, respectively; SL, NGS, NS, GW, Y and Ph indicate; spike length, number of grain per spike, 1000 -grains weight, grain yield per plant and plant height, respectively

t, †† and t†t indicate; 1.6E-4, 7.3E-5 and 1.05E-4; Tem, Flu, RCC and RWC indicate; leaf temperature, fluorescence chlorophyll, relative chlorophyll content and relative water content, respectively 
252

50.55 for 'Rihane- 05 ' to 67.48 for 'Badia Kavirr' genotype under non-stress condition and ranged from 40.85 for '168.4 Lign131' genotype to 59.48 for 'Mahabad' landrace under stress conditions. The highest reduction (29.29\%) in plant height due to stress was observed in '168.4 Lign 131' genotype. The decrease in plant height under drought stress condition could be due to decrease in relative turgidity and dehydration of protoplasm which is associated with loss of turgor and reduced cell division and cell expansion (Bayoumi et al., 2008). Number of grains per spike ranged from 31.75 for 'Rihaner' genotype to 35.50 for 'Badia Kavirr' under non-stress condition, and ranged from 31.50 for 'Naghadeh' landrace to 43.50 for
'Rihane- 05 ' under stress condition. The highest reduction $(2.87 \%)$ in grains per spike due to stress was observed in 'Piranshahr' landrace. In the study conducted by Pour Aboughadareh (2012), in the wild wheat number of grains per spike showed lower reduction under stress conditions than other component yield. 'Rihaner' and 'Atlas46/Kavir' barley genotype produced the highest 1000-grain weight and spike length under non-stress condition, while under stress condition the highest 1000 -grain weight and spike length related to 'Naghadeh' landrace and 'CB' genotype, respectively. The highest reduction in spike length and 1000 -grain weight due to stress condition was observed in 'Rihane-05' genotype and 'Naghadeh' landrace, respecTab. 3. Mean of agro-morphological and physiological characteristics in genotypes and landraces of barley under normal $(\mathrm{N})$ and water deficit stress $(S)$ conditions and percent of reduction $(\% R)$

\begin{tabular}{|c|c|c|c|c|c|c|c|c|c|c|c|}
\hline Code & & Tem & Flu & RCC & RWC & SL & NS & NGS & GW & $\mathrm{Ph}$ & $\mathrm{Y}$ \\
\hline \multirow{3}{*}{1} & $\mathrm{~N}$ & $23.12 \mathrm{ab}$ & $0.79 \mathrm{ab}$ & $42.62 \mathrm{ab}$ & $80.76 \mathrm{ab}$ & $9.65 \mathrm{ab}$ & $5.25 \mathrm{ab}$ & $35.50 \mathrm{a}$ & $38.82 \mathrm{ab}$ & $67.48 \mathrm{a}$ & $7.17 \mathrm{ab}$ \\
\hline & S & $30.12 \mathrm{cde}$ & $0.70 \mathrm{~cd}$ & $0.70 \mathrm{cde}$ & $35.15 \mathrm{~cd}$ & $6.63 \mathrm{cde}$ & $1.25 \mathrm{~cd}$ & $38.00 \mathrm{bc}$ & $26.30 \mathrm{bcd}$ & $64.20 \mathrm{a}$ & $1.24 \mathrm{~cd}$ \\
\hline & $\% \mathrm{R}$ & -30.27 & 11.11 & 11.11 & 17.54 & 31.35 & 76.19 & -7.04 & 32.26 & 4.85 & 82.79 \\
\hline \multirow{3}{*}{2} & $\mathrm{~N}$ & $25.12 \mathrm{de}$ & $0.75 \mathrm{~cd}$ & $40.67 \mathrm{ef}$ & $77.48 \mathrm{ef}$ & $8.58 \mathrm{~cd}$ & $3.50 \mathrm{c}$ & $33.50 \mathrm{a}$ & $42.35 \mathrm{ab}$ & $57.78 \mathrm{f}$ & $4.94 \mathrm{~d}$ \\
\hline & S & $29.50 \mathrm{bcde}$ & $0.71 b c$ & $0.71 \mathrm{bcd}$ & $36.30 \mathrm{bcd}$ & $7.13 \mathrm{bcd}$ & $2.00 \mathrm{bcd}$ & $37.75 b c$ & $26.37 \mathrm{bcd}$ & $40.85 \mathrm{k}$ & $1.98 \mathrm{~cd}$ \\
\hline & $\% \mathrm{R}$ & -17.41 & 5.45 & 5.46 & 10.76 & 16.91 & 42.86 & -12.69 & 37.72 & 29.29 & 59.89 \\
\hline \multirow{3}{*}{3} & $\mathrm{~N}$ & $24.37 \mathrm{bcde}$ & $0.76 \mathrm{bcd}$ & $41.20 \mathrm{cde}$ & $78.63 \mathrm{cde}$ & $8.80 \mathrm{bcd}$ & $4.25 b c$ & $35.00 \mathrm{a}$ & $38.80 \mathrm{ab}$ & $64.28 \mathrm{~b}$ & $5.77 \mathrm{bcd}$ \\
\hline & S & $29.12 b c$ & $0.71 b c$ & $0.71 b c$ & $37.35 b c$ & $7.60 \mathrm{bc}$ & $2.25 b c$ & $35.50 \mathrm{bcd}$ & $28.07 \mathrm{abc}$ & $59.48 b$ & $2.22 \mathrm{bc}$ \\
\hline & $\% \mathrm{R}$ & -19.48 & 6.47 & 6.48 & 9.34 & 13.64 & 47.06 & -1.43 & 27.64 & 7.47 & 61.53 \\
\hline \multirow{3}{*}{4} & $\mathrm{~N}$ & $24.62 \mathrm{cde}$ & $0.76 \mathrm{~cd}$ & $41.07 \mathrm{def}$ & 78.16def & $8.93 \mathrm{bcd}$ & $4.00 \mathrm{bc}$ & $31.75 \mathrm{a}$ & $45.57 \mathrm{a}$ & $59.65 \mathrm{e}$ & $5.79 \mathrm{bcd}$ \\
\hline & S & $28.50 \mathrm{~b}$ & $0.72 b$ & $0.72 \mathrm{ab}$ & $38.40 \mathrm{~b}$ & $8.00 \mathrm{ab}$ & $3.00 \mathrm{~b}$ & $32.25 \mathrm{~d}$ & $31.15 a$ & $50.83 f$ & $2.98 b$ \\
\hline & $\% \mathrm{R}$ & -15.73 & 4.60 & 4.61 & 6.51 & 10.36 & 25.00 & -1.57 & 31.65 & 14.79 & 48.47 \\
\hline \multirow{3}{*}{5} & $\mathrm{~N}$ & $23.37 \mathrm{abc}$ & $0.78 \mathrm{ab}$ & $42.27 \mathrm{abcd}$ & $80.38 \mathrm{abcd}$ & $9.43 \mathrm{abc}$ & $4.75 \mathrm{abc}$ & $35.75 \mathrm{a}$ & $38.07 \mathrm{~b}$ & $60.70 \mathrm{~d}$ & 6.45abcd \\
\hline & S & $27.50 \mathrm{a}$ & $0.74 a$ & $0.74 a$ & $40.77 \mathrm{a}$ & $9.03 a$ & $4.25 a$ & $31.50 \mathrm{~d}$ & $31.47 \mathrm{a}$ & $55.60 \mathrm{~d}$ & $4.21 \mathrm{a}$ \\
\hline & $\% \mathrm{R}$ & -17.64 & 5.90 & 5.91 & 3.55 & 4.24 & 10.53 & 11.89 & 17.33 & 8.40 & 34.65 \\
\hline \multirow{3}{*}{6} & $\mathrm{~N}$ & $22.75 a$ & $0.80 \mathrm{a}$ & $43.07 \mathrm{a}$ & $81.50 \mathrm{a}$ & $10.10 \mathrm{a}$ & $5.75 \mathrm{a}$ & $32.00 \mathrm{a}$ & $45.17 \mathrm{ab}$ & $55.48 \mathrm{~h}$ & $8.25 a$ \\
\hline & S & $30.25 \mathrm{de}$ & $0.70 \mathrm{~cd}$ & $0.70 \mathrm{de}$ & $34.70 \mathrm{~cd}$ & $6.48 \mathrm{de}$ & $1.25 \mathrm{~cd}$ & $40.75 \mathrm{ab}$ & $24.35 \mathrm{~cd}$ & $49.13 \mathrm{~g}$ & $1.24 \mathrm{~cd}$ \\
\hline & $\% \mathrm{R}$ & -32.96 & 12.48 & 12.48 & 19.44 & 35.89 & 78.26 & -27.34 & 46.10 & 11.45 & 84.95 \\
\hline \multirow{3}{*}{7} & $\mathrm{~N}$ & $25.62 e$ & $0.74 d$ & $39.95 \mathrm{f}$ & $77.32 \mathrm{e}$ & $8.35 \mathrm{~d}$ & $3.50 \mathrm{c}$ & $33.50 \mathrm{a}$ & $42.85 \mathrm{ab}$ & $60.45 \mathrm{~d}$ & $4.97 \mathrm{~cd}$ \\
\hline & S & $28.50 \mathrm{~b}$ & $0.72 b$ & $0.72 \mathrm{ab}$ & $38.60 \mathrm{~b}$ & $8.15 a b$ & $3.00 \mathrm{~b}$ & $34.50 \mathrm{~cd}$ & $28.60 \mathrm{abc}$ & $51.45 f$ & $2.95 b$ \\
\hline & $\% \mathrm{R}$ & -11.21 & 2.58 & 2.58 & 3.38 & 2.40 & 14.29 & -2.99 & 33.26 & 14.89 & 40.67 \\
\hline \multirow{3}{*}{8} & $\mathrm{~N}$ & $22.75 a$ & $0.80 \mathrm{a}$ & $42.77 \mathrm{ab}$ & $81.46 a b$ & $10.00 \mathrm{a}$ & $5.75 \mathrm{a}$ & $33.25 \mathrm{a}$ & $42.37 \mathrm{ab}$ & $57.28 \mathrm{~g}$ & $8.05 \mathrm{a}$ \\
\hline & S & $29.25 \mathrm{bcd}$ & $0.71 b c$ & $0.71 \mathrm{bcd}$ & $36.52 \mathrm{bcd}$ & $7.20 \mathrm{bcd}$ & $2.00 \mathrm{bcd}$ & $36.75 \mathrm{bcd}$ & $27.32 \mathrm{abc}$ & $53.45 e$ & $1.96 \mathrm{~cd}$ \\
\hline & $\% \mathrm{R}$ & -28.57 & 11.01 & 11.01 & 14.61 & 28.00 & 65.22 & -10.53 & 35.52 & 6.68 & 75.65 \\
\hline \multirow{3}{*}{9} & $\mathrm{~N}$ & 24.12abcd & $0.77 b c$ & 41.62bcde & 79.40 bcde & $8.95 \mathrm{bcd}$ & $4.75 \mathrm{abc}$ & $34.00 \mathrm{a}$ & $41.07 \mathrm{ab}$ & $54.40 \mathrm{i}$ & 6.58abcd \\
\hline & S & $29.12 b c$ & $0.72 \mathrm{bc}$ & $0.72 b c$ & $37.27 b c$ & $7.48 \mathrm{bcd}$ & $2.25 b c$ & $36.25 \mathrm{bcd}$ & $27.35 \mathrm{abc}$ & $46.55 \mathrm{~h}$ & $2.21 b c$ \\
\hline & $\% \mathrm{R}$ & -20.72 & 7.28 & 7.29 & 10.45 & 16.48 & 52.63 & -6.62 & 33.41 & 14.43 & 66.36 \\
\hline \multirow{3}{*}{10} & $\mathrm{~N}$ & $23.37 \mathrm{abc}$ & $0.79 \mathrm{ab}$ & $42.22 \mathrm{abcd}$ & $80.53 \mathrm{abcd}$ & $9.28 \mathrm{abcd}$ & $4.75 a b c$ & $34.75 a$ & $39.52 \mathrm{ab}$ & $61.50 \mathrm{c}$ & 6.48abcd \\
\hline & S & $28.62 b$ & $0.72 b$ & $0.72 b$ & $38.20 b c$ & $8.03 \mathrm{ab}$ & $2.50 \mathrm{~b}$ & $33.75 \mathrm{~cd}$ & $29.55 \mathrm{ab}$ & $57.50 \mathrm{c}$ & $2.45 b$ \\
\hline & $\% \mathrm{R}$ & -22.45 & 8.37 & 8.37 & 9.53 & 13.48 & 47.37 & 2.88 & 25.24 & 6.50 & 62.16 \\
\hline \multirow{3}{*}{11} & $\mathrm{~N}$ & 23.75abcd & $0.78 \mathrm{ab}$ & $42.17 \mathrm{abcd}$ & $80.33 \mathrm{abcd}$ & $9.30 \mathrm{abcd}$ & $5.00 \mathrm{ab}$ & $34.25 a$ & $40.85 \mathrm{ab}$ & $52.18 j$ & $6.92 \mathrm{abc}$ \\
\hline & S & $28.62 b$ & $0.72 b$ & $0.72 b$ & $38.07 \mathrm{~b}$ & $7.95 \mathrm{ab}$ & $2.50 \mathrm{~b}$ & $36.25 \mathrm{bcd}$ & $27.40 \mathrm{abc}$ & $44.03 \mathrm{i}$ & $2.47 b$ \\
\hline & $\% \mathrm{R}$ & -20.52 & 7.94 & 7.94 & 9.72 & 14.52 & 50.00 & -5.84 & 32.93 & 15.62 & 64.35 \\
\hline \multirow{3}{*}{12} & $\mathrm{~N}$ & $23.37 \mathrm{abc}$ & $0.79 \mathrm{ab}$ & $42.45 \mathrm{abc}$ & $80.67 \mathrm{abc}$ & $9.55 \mathrm{abc}$ & $5.00 \mathrm{ab}$ & $35.00 \mathrm{a}$ & $39.60 \mathrm{ab}$ & $50.55 \mathrm{k}$ & 6.89abc \\
\hline & S & $30.50 \mathrm{~d}$ & $0.69 \mathrm{~d}$ & $0.69 \mathrm{e}$ & $33.15 d$ & $5.83 \mathrm{e}$ & $1.00 \mathrm{~d}$ & $43.50 \mathrm{a}$ & $22.77 d$ & $42.73 j$ & $0.99 \mathrm{~d}$ \\
\hline & $\% \mathrm{R}$ & -30.48 & 11.85 & 11.86 & 21.91 & 39.01 & 80.00 & -24.29 & 42.49 & 15.48 & 85.63 \\
\hline
\end{tabular}

Different letter in each column indicate significant difference at $p \leq 0.05$.

Tem, Flu, RCC, RWC, SL, NGS, NS, GW, Y and Ph indicate; leaf temperature, fluorescence chlorophyll, relative chlorophyll content (SPAD), relative water content, spike length, number of grain per spike, 1000-grains weight, grain yield per plant and plant height, respectively. 
tively. Riaz and Choudhy (2003) reported that genotypes with high 1000-grain weight under irrigated conditions may not be superior for this trait under moisture stress conditions. This is possible due to the limitation of moisture which forces plant to complete its grain filling in relatively shorter duration (Fayaz and Arzani, 2011). Number of grain per spike and 1000-grain weight decreased under water deficit stress condition. Probably water deficit caused male sterility which may in turn reflected in abortion of terminal and basal florets; hence, reduction in number of grain per spike and flowed by grain weight (Saini and Aspinall, 1981). In durum wheat Garcia del moral et al. (2005) observed $18.5 \%$ of reduction in number of grain per spike due to the negative effect of moisture stress. Also, 'Atlas46/ Kavir' 'Rihane-05' genotypes produced the highest and lowest grain yield than all genotypes and landraces under non-stress and stress, respectively. The highest reduction (85\%) related to 'Rihane- 05 ' genotype. Kirby and Jones (1997) and Giunta et al. (1993) also reported that mean decreased in grain yield under drought stress. In addition, decline of grain yield and components yield reported in many researches (Gooding et al., 2003; Ozturk and Aydin, 2004; Shah and Paulsenl, 2003; Wardlaw, 2002).

Correlation studies are useful in measuring the strength and the direction of these relationships among the different characters and grain yield (Gashaw et al., 2007). So, to study the relationship, simple correlation between each pair of the characteristics for both conditions was calculated (Tab. 4). Based on correlation analysis, all the characters included in the study except leaf temperature and number of grain per spike showed significant $(p \leq 0.01)$ positive correlation with grain yield under both conditions. Garcia del Moral et al. (2003) reported that the number of spikes per squares meter in durum wheat was positively related to grain yield under rain fed conditions. In terms of physiological characters high significant $(p \leq 0.01)$ correlation coefficient was found between relative water content and grain yield under stress condition; however, high significant $(p \leq 0.01)$ correlation coefficient was found between fluorescence chlorophyll and grain yield under non-stress condition. Significant $(p \leq 0.01)$ and negative correlation coefficient was found between grain

Tab. 4. Correlation coefficient between physiological traits, grain yield and its components under normal (above diameter) and water deficit stress conditions (below diameter)

\begin{tabular}{|c|c|c|c|c|c|c|c|c|c|c|}
\hline & Tem & Flu & RCC & RWC & SL & NS & NGS & GW & $\mathrm{Y}$ & $\mathrm{Ph}$ \\
\hline Tem & 1 & -0.96 & $-0.97^{\prime \prime}$ & $-0.95^{\prime \prime}$ & $-0.91^{*}$ & -0.75 & $-0.12^{\mathrm{ns}}$ & $0.12^{\mathrm{ns}}$ & $-0.73^{* \prime}$ & $0.07^{\text {ns }}$ \\
\hline Flu & $-0.97^{*}$ & 1 & $0.97^{*}$ & $0.98^{* *}$ & $0.92^{* *}$ & $0.85^{\circ}$ & $0.14^{\mathrm{ns}}$ & $-0.15^{\mathrm{ns}}$ & $0.82^{*}$ & $-0.14^{\mathrm{ns}}$ \\
\hline RCC & $-0.98^{* \prime}$ & $0.98^{* \prime}$ & 1 & $0.95^{*}$ & $0.92^{*}$ & $0.79^{\circ "}$ & $0.19^{\text {ns }}$ & $-0.18^{\mathrm{ns}}$ & $0.77^{*}$ & $-0.13^{\mathrm{ns}}$ \\
\hline RWC & $-0.96^{*}$ & $0.98^{\prime \prime}$ & $0.97^{\circ}$ & 1 & $0.91^{*}$ & $0.84^{*}$ & $0.15^{\mathrm{ns}}$ & $-0.16^{\mathrm{ns}}$ & $0.82^{*}$ & $-0.15^{\mathrm{ns}}$ \\
\hline SL & $-0.97^{\prime \prime}$ & $0.97^{\prime \prime}$ & $0.99^{\prime \prime}$ & $0.96^{\circ}$ & 1 & $0.84^{*}$ & $0.07^{\mathrm{ns}}$ & $-0.05^{\mathrm{ns}}$ & $0.83^{\prime \prime}$ & $-0.11^{\mathrm{ns}}$ \\
\hline NS & $-0.91^{*}$ & $0.92^{*}$ & $0.90^{\circ}$ & $0.92^{*}$ & $0.89^{*}$ & 1 & $0.06^{\mathrm{ns}}$ & $-0.06^{\mathrm{ns}}$ & $0.98^{* *}$ & $-0.14^{\mathrm{ns}}$ \\
\hline NGS & $0.76^{*}$ & $-0.79^{\prime \prime}$ & $-0.78^{*}$ & $-0.77^{*}$ & $-0.77^{\prime \prime}$ & $-0.72^{*}$ & 1 & $-0.98^{* *}$ & $-0.07^{\mathrm{ns}}$ & $0.13^{\text {ns }}$ \\
\hline GW & $-0.72^{* \prime}$ & $0.76^{*}$ & $0.74^{*}$ & $0.74^{*}$ & $0.72^{*}$ & $0.70^{*}$ & $-0.98^{* \prime}$ & 1 & 0.086 & $-0.15^{\mathrm{ns}}$ \\
\hline Y & $-0.91^{*}$ & $0.92^{\prime \prime}$ & $0.90^{\circ}$ & $0.92^{*}$ & $0.88^{* *}$ & $1.00^{\circ}$ & $-0.71^{*}$ & $0.70^{* *}$ & 1 & $-0.17^{\mathrm{ns}}$ \\
\hline $\mathrm{Ph}$ & $-0.15^{\mathrm{ns}}$ & $0.15^{\mathrm{ns}}$ & $0.20^{\mathrm{ns}}$ & $0.17^{\mathrm{ns}}$ & $0.20^{\mathrm{ns}}$ & $0.11^{\mathrm{ns}}$ & $-0.28^{*}$ & $0.27^{\mathrm{ns}}$ & $0.11^{\mathrm{ns}}$ & 1 \\
\hline
\end{tabular}

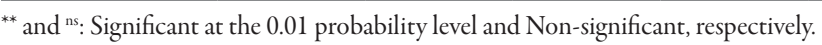

Tem, Flu, RCC, RWC, SL, NGS, NS, GW, Y and Ph indicate; leaf temperature, fluorescence chlorophyll, relative chlorophyll content (SPAD), relative water content, spike length, number of grain per spike, 1000-grains weight, grain yield per plant and plant height, respectively.

Tab. 5. Grain yield and stress susceptibility index (SSI) of genotypes and landraces of barley under normal (Yn) and water deficit stress (Ys) conditions

\begin{tabular}{cccc}
\hline Genotype/landrace & Yp (gr per plant) & Ys (gr per plant) & SSI \\
\hline 'Badia Kavirr' & 7.17 & 1.24 & 1.26 \\
\hline '168.4 Lign131/Abrabi Abiad' & 4.94 & 1.98 & 0.91 \\
\hline 'Mahabad' & 5.77 & 2.22 & 0.94 \\
\hline 'Rihaner' & 5.79 & 2.98 & 0.74 \\
\hline 'Naghadeh' & 6.45 & 4.21 & 0.53 \\
\hline 'Atlas46/Kavir' & 8.25 & 1.24 & 1.29 \\
\hline 'CB' & 4.97 & 2.95 & 0.62 \\
\hline 'Sahand' & 8.05 & 1.96 & 1.15 \\
\hline 'Makoobi' & 6.58 & 2.21 & 1.01 \\
\hline 'Piranshahr' & 6.48 & 2.45 & 0.95 \\
\hline 'CW3117-77-5-9-5' & 6.92 & 2.47 & 0.98 \\
\hline 'Rihane-05' & 6.89 & 0.99 & 1.30 \\
\hline
\end{tabular}


254

yield per plant and number of grain per spike under stress condition. 1000-grain weight also had negative correlation with all characters except leaf temperature under nonstress condition. However, this character had significant $(p \leq 0.01)$ and positive correlation with fluorescence chlorophyll, relative water content, SPAD value, spike length, number of spike per plant under stress condition (Tab. 4). These results are in agreement with the previous reported results on landraces of wheat under stress condition (Farshadfar et al., 2012). Moghaddam et al. (1997) reported negative correlation between number of grain per spike and 1000-grain weight. In the studies conducted by Sinha and Sharma (1979) and Belay et al. (1993), grain yield was positively correlated with each of the three primary grain yield components, with either positive or negative correlation between grain yield and plant height.

Stress susceptibility index (SSI) was used as a selection criterion of drought tolerant in terms of minimization of yield reduction caused by drought stress as compared with non-stress conditions. Calculated SSI varied in from 0.62 to 1.30 for genotypes, and ranged from 0.53 to 1.15 for landraces (Tab. 5). 'Naghadeh' and 'Sahand' landraces that had the lowest and highest SSI values were found to be the most tolerant and the most susceptible landraces, respectively. Also, 'CB' and 'Rihane- 05 ' genotypes that had the lowest and highest value were found to be the most tolerant and susceptible genotypes, respectively. This was in agreement with conclusions made based on agro-morphological and physiological characteristics. Fayaz and Arzani (2011) reported cultivars with low SSI values are moisture resistant because they have lesser reduction in grain yield under stress compared with non-stress condition. Nevertheless, this index per se appears to have serious limitations for the quantification of genotype reaction to moisture conditions, because it is based on minimizing yield reduction in stress compared with non-stress conditions. Therefore, selection for low SSI would tend to reduce yield in non-stress conditions (Dencic et al., 2000). However, barley genotypes and landraces identified as the stress tolerant by SSI may have tolerant mechanism, and can be used as sources of drought stress resistance in barley breeding programs for development of secondary germplasm with high grain yield potential. Considering the grain yield potential 'Naghadeh', 'Mahabad', 'Piranshahr' landraces and CW3117-77 genotypes were ranked as the superior group of drought tolerant barley. On the other hand, 'Naghadeh' landrace was identified as a barley landrace that could be grown under both normal and water deficit stress conditions with high grain yield.

\section{Conclusions}

This paper proposes a strategy to select the traits to be used in breeding programs. The result obtained from this study could be useful for barley breeders and seed producer in order to increase grain yield in water deficit con- ditions. The changes of characters relationship in barley seed under different irrigation condition should be considered for variety selection and every plant breeding program of the plant. Screening drought tolerant genotypes and landraces using compare mean and SSI discriminated 'Naghadeh' landrace and 'CW3117-77' genotype as the most drought tolerant. Therefore they are recommend to be used as parents for improvement of drought tolerance in other cultivars.

\section{References}

Ahmadi M, Farshadfar E, Veisi S (2012). Evaluation of genetic diversity in bread landrace of bread wheat under irrigated and rainfed conditions. Inter J Agri Crop Sci 4(21):16271636.

Araus JL, Salfer M P, Royo C, Serett M D (2008). Breeding for yield potential and stress adaptation in cereals. Critical Rev in Plant Sci 27:377-412.

Baik BK, Ullrich SE (2008). Barley for food: Characteristics, improvement, and renewed interest. J Cereal Sci 48(2):233242.

Bayoumi TY, Eid MH, Metwali MM (2008). Application of physiological and biochemical indices as a screening technique for drought tolerance in wheat genotypes. Afr J Biotech 7:2341-2352.

Belay G, Tesemma T, Becker HC, Merker A (1993). Variation and interrelationships of agronomic traits in Ethiopian tetraploid wheat landraces. Euphytica 71:181-188.

Betran FJ, Beck D, Banziger M, Edmeades GO (2003). Genetic analysis of inbred and hybrid grain yield under stress and non-stress enviroments in tropical maize. Crop Sci 43:807817.

Brush SB (1995). In situ conservation of landraces in centers of crop diversity. Crop Sci 35:346-354.

Byrne PF, Bolanos J, Edmeades GO, Eaton DL (1995). Grains from selection under drought versus multi location testing in related tropical maize populations. Crop Sci 35:63-69.

Cao HX, Sun CX, Shao HB, Lei XT (2011). Effects of low temperature and drought on the physiological and growth changes in oil palm seedlings. African Journal of Biotechnology 10:2630-2637.

Ceccarelli S, Grando S (2000). The environment selection and environmental sensitivity in barley. Euphytica 57:57-167.

Clarke J M, DePauw RM, Townley-Smith TF (1992). Methods evaluation of quantification for drought tolerance in wheat. Crop Sci 32:723-728.

Crudacea AJ (2000). The investigation of the in vivo behavior of maize herbicide-Isoxaflutole. $\mathrm{PhD}$ thesis. University of Essex, Colcherter, UK.

Dencic S, Kastori R, Kobiljski B, Duggan B (2000). Evaluation of grain yield and its components in wheat cultivars and landraces under near optimal and drought conditions. Euphytica 113:43-52. 
Erdei L, Tari I, Csiszar J, Pecsvaradi A, Horvath F, Szabo M, Ordog M, Cseuz L, Zhiponova M, Szilak L, Gyorgyey L (2002). Osmotic stress responses of wheat species and cultivars differing in drought tolerance: some interesting genes (advices for gene hunting). Acta Biol Szeged 46:63-65.

Farshadfar E (2012). Application of integrated selection index and rank sum for screening drought tolerant genotypes in bread wheat. Inter J Agri Crop Sci 4(6):325-332.

Farshadfar E, Farshadfar M, Dabiri S (2012). Comparison between effective selection criteria of drought tolerance in bread wheat landraces of Iran. Annals of Biological Research $3(7): 3381-3389$.

Fayaz N, Arzani A (2011). Moisture stress tolerance in reproductive growth stages in triticale (X Triticosecale Wittmack) cultivars under field conditions. Crop Breeding Journal $1(1): 1-12$.

Fernandez GCJ (1992). Effective selection criteria for assessing plant stress tolerance, 257-270 p. In: Proceedings of the international symposium on adaptation of vegetables and other food crops in temperature and water stress, Taiwan 13-16 August 1992.

Fischer RA, Maurer R (1978). Drought resistance in spring wheat cultivars; I. Grain yields responses. Aust J Agric Res 29:897-912.

Garci A, Del Moral LF, Rharrabti Y, Villegas D, Royo C (2003) Evaluation of grain yield and its components in durum wheat under mediterranean conditions: An ontogenic approach. Agron J 95:266-274.

Gashaw A, Mohammed H, Singh H (2007). Selection criterion for improved grain yields in Ethiopian durum wheat genotypes. Afr Crop Sci J 15(1):25-31.

Giunta F, Motzo R, Deidda M (1993). Effect of drought on yield and yield components of durum wheat and triticale in Mediterranean environment. Field Crops Res 33(4):399-409.

Gooding MJ, Ellis RH, Shewry, PR, Schofield JD (2003). Effects of restricted water availability and increased temperature on the grain filling, drying and quality of winter wheat. JCereal Sci 37:295-309.

Gupta NK, Gupta S, Kumar A (2001). The effect of water stress on physiological attributes and its relationship with growth and yield of wheat cultivars at different stages. Crop Sci 186:55-62.

Kirby EJM, Jones HG (1997). The relations between the main shoot and tillers in barley. J Agric Sci 88:381-389.

Moghaddam M, Ehdaie B, Waines JG (1997). Genetic variation and interrelationships of agronomic characters in landraces of bread wheat from southeastern Iran. Euphytica 95:361369.

Ozturk A, Aydin F (2004). Effect of water stress at various stages on some quality characteristics of winter wheat. J Agron Crop Sci 190:93-99.
Percival MP, Baker NR (1991). Herbicides and ohotosynthesis. In: Baker NR, Percival MP (Eds.). Herbicides. Elsevier, Amsterdam.

Pour Aboughadareh AR (2012). Evaluation of Triticum boeoticum and Triticum urartu populations based on morphological characteristics under normal and water stress conditions. M.Sc Thesis. University of Tabriz, Tabriz, Iran.

Rajaram S, Van Ginkle M (2001). Mexico, 50 years of international wheat breeding. In: Bonjean AP, Angus WJ (Eds.). The World Wheat Book: A History of Wheat Breeding. Lavoisier Publishing, Paris, France.

Rampino P, Pataleo S, Gerardi C, Mita G, Perrotta C (2006). Drought stress response in wheat: physiological and molecular analysis of resistant and sensitive genotypes. Plant Cell Environ 29:2143-2152.

Rathjen AJ (1994). The biological basis of genotype $\times$ environment interaction: its definition and management. Proceedings of the Seventh Assembly of the Wheat Breeding Society of Australia, Adelaide, Australia.

Riaz R, Choudhary MA (2003). Genetic analysis of some economic traits of wheat under drought condition. Asian J Plant Sci 2:790-796.

Richards RA (1996). Defining selection criteria to improve yield under drought. Plant Growth Regul 20:157-166.

Rong-Hua L, Peiguo G, Baum M, Grando S, Ceccarelli S (2006). Evaluation of chlorophyll content and fluorescence parameters as indicators of drought tolerance in barley. Agric Sci Chin 5:751-757.

Saini HS, Aspinall D (1981). Effect of water deficit on sporogenesis in wheat (Triticum aestivum L.). Ann Bot 43:623633.

Sanchez-Rodriguez E, Rubio-Wilhelmi M, Cervilla LM, Blasco B, Rios JJ, Rosales MA, Romero L, Ruiz JM (2010). Genotypic differences in some physiological parameters symptomatic for oxidative stress under moderate drought in tomato plants. Plant Sci 178:30-40.

Shah NH, Paulsen 1 GM (2003). Interaction of drought and high temperature on photosynthesis and grain- filling of wheat. Plant Soil 257:219-226.

Sinha GCP, Sharma NN (1979). Correlation regression and path analysis studies in wheat varieties. Indian J Agron 25:225-229.

Slapakauskas V, Ruzgas V (2005). Chlorophyll fluorescence characteristics of different winter wheat varieties (Triticum aestivum L.). Agronomy Research 3(2):203-209.

Turner NC (1986). Crop water deficit: A decade of progress, Adv Agron 39:1-51.

Wardlaw IF (2002). Interaction between drought and chronic high temperature during kernel filling in wheat in a controlled environment. Ann of Bot 80:469-476. 